Note

\title{
A Seasonality in the Pakistani Equity Market: The Ramadhan Effect
}

\author{
FAZAL HUSAIN
}

\begin{abstract}
This paper attempts to explore a seasonal pattern, the Ramadhan effect, in the Pakistani equity market. Ramadhan, the holy month of fasting, is expected to affect the behaviour of stock market in Pakistan where the environment in Ramadhan is different from other months as people devote more time to perform religious rituals and the general economic activity slows down. The effects of Ramadhan on mean return and stock returns volatility are examined by including a dummy variable in regressions and GARCH models respectively. The analysis indicates a significant decline in stock returns volatility in this month although the mean return indicates no significant change.
\end{abstract}

\section{INTRODUCTION}

An interesting exercise in finance literature has been to see if any seasonal patterns exist in stock returns. A predictable pattern is an evidence against market efficiency, and can provide useful clues to investors regarding their investment decisions. The different patterns identified in stock returns include the day of the week effect, the day of the month effect, the end of the year effect, etc. French (1980), Gibbons and Hess (1981), Keim (1983), Gultekin and Gultekin (1983), Harris (1986), Ariel (1987), Broca (1992), etc., report these seasonal patterns.

However, another pattern that can be explored in Islamic countries is the Ramadhan effect. Ramadhan, the ninth month of the Islamic calendar, is a month of fasting and is generally observed with religious fervor. Fasting in Islam requires complete abstinence from eating and drinking from dawn to sunset. In addition, Muslims are urged, with special emphasis, to refrain from wrong-doing. Most important, many Muslims may tend to refrain from participating in stock market in this

Fazal Husain is Research Economist, Pakistan Institute of Development Economics, Islamabad.

Author's Note: The author is grateful to Dr Reza Saidi for his suggestion to explore this seasonality. The author is also thankful to anonymous referees of this journal for their helpful comments on an earlier version of this paper. 
month, considering it a form of gambling. Hence it seems to be important to examine whether the behaviour of stock returns during Ramadhan is any different from that in other months. The purpose of this paper is to conduct such an exercise in Pakistan, an Islamic state with more than 95 percent Muslim population.

In Pakistan, as in other Muslim countries, the environment in the month of Ramadhan is different from that in other months. People observe fasting, visit mosques frequently, pray regularly, participate more in social services, etc. The restaurants and cafés are closed during daytime. The general economic activity in all walks of life slows down as people devote more time to the performance of rituals. The working hours, including the trading hours at the exchange, are also reduced. Hence, it would be interesting to examine the behaviour of stock returns under such conditions.

The remainder of the paper is organised as follows. The next section explains the data sources and methodology, whereas the results and conclusions are presented in Section III.

\section{DATA SOURCES AND METHODOLOGY}

The analysis was conducted on daily stock prices and indices, selected from the Karachi Stock Exchange (KSE), the main equity market in Pakistan. ${ }^{1}$ The data consist of 36 individual stocks, 8 sector indices, and the general market index, covering the period from January 1, 1989 to December 30, 1993.

Information on individual stocks regarding closing prices, volumes, dividends, and rights issues was collected from the Exchange (KSE), the Corporate Law Authority (a body that regulates stock exchanges in Pakistan), and the Business Recorder (a daily newspaper). The data on sector indices as well as the market index were obtained from the State Bank of Pakistan, the central bank, which prepares and maintains these indices.

The return $\left(R_{t}\right)$ on a stock, following conventions, was estimated as the first difference of the natural log of stock prices $\left(P_{t}\right)$, that is,

$$
R_{t}=\ln P_{t}^{\prime}-\ln P_{t-1}
$$

where $P_{t}^{\prime}$ is the price of a stock at time $t$ adjusted for capital changes, i.e., dividends, rights issues, etc. To examine the effects of Ramadhan on mean return, the following regression was estimated,

$$
R_{t}=\lambda_{0}+\lambda_{1} D_{t}
$$

where $D=1$ for Ramadhan period and 0 otherwise.

${ }^{1}$ Readers may like to see Mirza (1993) and Khan (1993) for comprehensive information regarding the evolution, regulations, and operations of the Pakistani equity market, particularly the KSE. 
To examine the Ramadhan effects on stock returns volatility, the following GARCH model was estimated,

$$
\begin{aligned}
& R_{t}=\lambda_{0}+\lambda_{1} D_{t}+\sum_{i=1}^{k} \beta_{i} R_{t-i}+e_{t} \\
& e_{t} \mid \psi_{t-1} \sim N\left(0, h_{t}\right) \\
& h_{t}=\delta_{0}+\delta_{1} D_{t}+\sum_{i=1}^{p} \alpha_{i} e_{t-i}^{2}+\sum_{j=p+1}^{q} \alpha_{j} h_{t-j}
\end{aligned}
$$

where the return was modelled as an autoregresive process of order $k$, determined by the Ljung Box (LB) values of the residuals. Similarly, the orders of $p$ and $q$ in the conditional variance, a linear function of past squared errors and lagged variances, were determined by the LB values of the normalised squared residuals. The dummy variable, $D$, was used to examine the Ramadhan effects.

\section{RESULTS AND CONCLUSIONS}

Table 1 shows the effects of Ramadhan on both the mean and the volatility of stock returns. " $D$ ” for both mean and volatility tests is the dummy variable that indicates the differences in mean and volatility in the month of fasting. For the sake of simplicity, only the results of the variance equation from GATCH model are reported under volatility.

The Table shows that although stock returns decline in the month of Ramadhan, the reduction, in general, is not significant. Hence, it can be concluded that the Ramadhan does not significantly affect the average return in the market. On the other hand, there is strong evidence of a significant decline in the volatility of stock returns in this month. The decline in volatility may be attributed to the generally slow pace of economic activity, including reduction in trading hours in Pakistan in the month of Ramadhan. On the other hand, many Muslims may refrain from stock market speculation in this month. Hence, whether it is the moral factor or the reduced trading hours that is responsible for the decline in volatility needs further investigation, and future research in this area can provide useful clues.

It is noteworthy that the average return does not change significantly in Ramadhan. With reduced volatility, this offers an attractive opportunity to investors. However, any benefits in this regard will soon vanish as speculative trading will increase. 
Table 1

Shifts in Mena Return and Stock Returns Volatility in Ramadhan for the Sample Period (Jan 89 - Dec 93)

\begin{tabular}{|c|c|c|c|c|c|c|c|}
\hline & \multicolumn{2}{|c|}{ Mean } & \multicolumn{5}{|c|}{ Volatility } \\
\hline & CONST (\%) & $\mathrm{D}$ & C*10000 & $\mathrm{D}$ & $\mathrm{e}(-1) * 2$ & $\mathrm{e}(-2) * 2$ & $\mathrm{~h}(-1)$ \\
\hline Gen. Index & $0.117^{* *}$ & -0.075 & $0.010^{* *}$ & -0.004 & $0.307 * *$ & & $0.723 * *$ \\
\hline \multicolumn{8}{|l|}{ Sector Indices } \\
\hline 1. Text & $0.063^{* *}$ & 0.024 & $0.038^{* *}$ & 0.002 & $0.316^{* *}$ & & $0.664 * *$ \\
\hline 2. Chem & $0.148 * *$ & $-0.195^{*}$ & $0.256^{* *}$ & $-0.141 * *$ & $0.241^{* *}$ & $0.278^{* *}$ & \\
\hline 3. Sugar & $0.061 * *$ & $-0.172 *$ & $0.273^{* *}$ & $-0.060 *$ & $0.645^{* *}$ & & \\
\hline 4. Paper & $0.087^{* *}$ & -0.042 & $0.10^{* *}$ & $-0.064 * *$ & $0.180^{* *}$ & & $0.718^{* *}$ \\
\hline 5. Cement & $0.168 * *$ & -0.082 & $0.179 * *$ & $-0.060 * *$ & $0.481^{* *}$ & & $0.455^{* *}$ \\
\hline 6. Fuel & $0.167 * *$ & $-0.257^{*}$ & $0.147^{* *}$ & $-0.088^{* *}$ & $0.442 * *$ & & $0.511 * *$ \\
\hline 7. Trans & 0.052 & 0.083 & $0.079 * *$ & 0.058 & $0.181^{* *}$ & & $0.828 * *$ \\
\hline 8. Insur & $0.078 *$ & 0.022 & $0.10^{* *}$ & $-0.045^{*}$ & $0.298^{*}$ & & $0.636^{* *}$ \\
\hline \multicolumn{8}{|l|}{ Securities } \\
\hline 1. GRINDL & $0.169 * *$ & -0.113 & $2.897 * *$ & $-1.713^{* *}$ & $0.258 * *$ & & $0.145^{*}$ \\
\hline 2. LTVC & 0.056 & 0.212 & $0.241^{* *}$ & -0.087 & $0.057 * *$ & & $0.919 * *$ \\
\hline 3. NDLC & $0.188 * *$ & -0.042 & $0.073^{* *}$ & $0.254^{* *}$ & $0.190 * *$ & & $0.827 * *$ \\
\hline 4. PICIC & $0.147^{* *}$ & -0.138 & $0.450 * *$ & -0.08 & $0.350 * *$ & & $0.559 * *$ \\
\hline 5. ADAMJEE & $0.266^{* *}$ & 0.128 & $0.303^{* *}$ & -0.016 & $0.128 * *$ & & $0.787 * *$ \\
\hline 6. SHAHM & $0.152 * *$ & -0.357 & $0.359 * *$ & 0.110 & $0.432 * *$ & & $0.530 * *$ \\
\hline 7. SHAKER & 0.063 & 0.022 & $1.166^{* *}$ & $0.447 * *$ & $0.450^{* *}$ & $0.145^{* *}$ & \\
\hline 8. PAKLA & $0.235^{* *}$ & -0.074 & $1.235^{* *}$ & $-0.743 * *$ & $0.317^{* *}$ & & $0.530 * *$ \\
\hline 9. PAKT & $0.190 * *$ & -0.257 & $0.528 * *$ & $-0.40 * *$ & $0.621 * *$ & & $0.449 * *$ \\
\hline 10. KESC & 0.133 & -0.024 & $0.184^{* *}$ & $-0.149 * *$ & $0.329 * *$ & & $0.703^{* *}$ \\
\hline 11. NATR & $0.202^{* *}$ & -0.061 & $0.338 * *$ & $-0.160 *$ & $0.422 * *$ & & $0.600^{* *}$ \\
\hline 12. PSO & $0.257^{* *}$ & -0.321 & $0.061^{* *}$ & -0.031 & $0.179 * *$ & & $0.824 * *$ \\
\hline 13. SUIN & $0.218 * *$ & -0.315 & $2.599 * *$ & $-1.351 * *$ & $0.639 * *$ & $0.262 * *$ & \\
\hline 14. SUIS & $0.182 *$ & -0.133 & $0.210^{* *}$ & $-0.159 * *$ & $0.407 * *$ & & $0.706^{* *}$ \\
\hline 15. GENT & $0.244^{* *}$ & -0.215 & $0.548^{* *}$ & $-0.367 * *$ & $0.188^{* *}$ & & $0.690 * *$ \\
\hline 16. MILLT & $0.122 *$ & -0.165 & $0.852 * *$ & $-0.574 * *$ & $0.499 * *$ & & $0.385^{* *}$ \\
\hline 17. PAKSU & 0.087 & -0.150 & $0.402^{* *}$ & $-0.335^{* *}$ & $0.163^{* *}$ & & $0.786^{* *}$ \\
\hline 18. PHILI & $0.195^{* *}$ & -0.025 & $1.05^{* *}$ & -0.048 & $0.341^{* *}$ & & $0.352 * *$ \\
\hline 19. PNSC & 0.106 & 0.056 & $2.621^{* *}$ & $-1.512^{* *}$ & $0.160^{* *}$ & & $0.694 * *$ \\
\hline 20. АВВОТТ & $0.139 * *$ & -0.114 & $0.900 * *$ & $-0.050 * *$ & $0.503^{* *}$ & & $0.631 * *$ \\
\hline 21. DAWOOD & 0.085 & -0.055 & $0.694^{* *}$ & $-0.540 * *$ & $0.420^{* *}$ & & $0.375^{* *}$ \\
\hline 22. ENGRO & $0.181^{* *}$ & -0.344 & $0.077^{* *}$ & 0.021 & $0.170 * *$ & & $0.823 * *$ \\
\hline 23. GLAXO & $0.165^{* *}$ & -0.013 & $0.255^{* *}$ & $-0.190 * *$ & $0.303^{* *}$ & & $0.548^{* *}$ \\
\hline 24. HOECHT & $0.181^{* *}$ & 0.037 & $0.786^{* *}$ & $-0.643 * *$ & $0.362 * *$ & & $0.384 * *$ \\
\hline 25. ICI & $0.177^{* *}$ & -0.046 & $0.103^{* *}$ & $-0.095 * *$ & $0.134 * *$ & & $0.846^{* *}$ \\
\hline 26. RECKI & $0.151^{* *}$ & -0.196 & $0.233^{* *}$ & $-0.099 * *$ & $0.143^{* *}$ & & $0.789 * *$ \\
\hline 27. WELLC & $0.221 * *$ & $0.425 *$ & $0.265^{* *}$ & -0.030 & $0.406^{* *}$ & & $0.631^{* *}$ \\
\hline 28. WYTH & $0.158^{* *}$ & $-0.299 *$ & $0.384^{* *}$ & $-0.127 *$ & $0.633^{* *}$ & $0.336^{* *}$ & \\
\hline 29. РACK & $0.189 * *$ & -0.170 & $0.107 * *$ & $-0.095 * *$ & $0.219 * *$ & & $0.746^{* *}$ \\
\hline 30. BATA & $0.104^{* *}$ & $-0.312 *$ & $0.305^{* *}$ & $-0.112^{* *}$ & $0.400 * *$ & & $0.470^{* *}$ \\
\hline 31. BROOK & $0.188 * *$ & 0.088 & $0.507 * *$ & -0.080 & $0.307 * *$ & & $0.350 * *$ \\
\hline 32. LEVER & $0.207^{* *}$ & -0.096 & $0.784 * *$ & -0.138 & $0.305^{* *}$ & & $0.365^{* *}$ \\
\hline 33. MILK & $0.156^{* *}$ & -0.187 & $0.144 * *$ & $0.140 * *$ & $0.241^{* *}$ & & $0.690 * *$ \\
\hline 34. RAFHAN & $0.183^{* *}$ & 0.088 & $1.08^{* *}$ & $-0.497 * *$ & $0.313^{* *}$ & $0.040 *$ & \\
\hline 35. SHEZ & $0.164^{* *}$ & -0.318 & $0.248 * *$ & 0.111 & $0.256^{* *}$ & & $0.640 * *$ \\
\hline 36. BALOCH & $0.164^{*}$ & -0.380 & $2.157^{* *}$ & $-1.086^{* *}$ & $0.317^{* *}$ & & $0.318^{* *}$ \\
\hline
\end{tabular}

1. D represents the shifts in mean and volatility of stock returns in Ramadhan (the month of fasting).

2. ** and * indicate significance level at 1 percent and 5 percent respectively. 


\section{REFERENCES}

Ariel, R. (1987) A Monthly Effect in Stock Returns. Journal of Financial Economics 18: $175-184$.

Broca, D. (1992) Day of the Week Patterns in the Indian Stock Market. Decision AprilJune : 57-64.

French, K. (1980) Stock Returns and the Weekend Effect. Journal of Financial Economics 8: 55-69.

Gibbons, M., and P. Hess (1981) Day of the Week Effects and Asset Returns. Journal of Business 54: 579-596.

Gultekin, M., and N. Gultekin (1983) Stock Market Seasonality: International Evidence. Journal of Financial Economics 12: 469-481.

Harris, L. (1986) A Transaction Data Study of Weekly and Intradaily Patterns in Stock Returns. Journal of Financial Economics 101-116.

Keim, D. (1983) Size-related Anomalies and Stock Return Seasonality: Further Empirical Evidence. Journal of Financial Economics June : 13-32.

Khan, M. S. (1993) The Securities Market in Pakistan. Pakistan: Royal Book Company.

Mirza, Khalid (1993) Pakistan: A Small Market with Potential. In Keith Park and Antoine Agtmael (ed) The World's Emerging Stock Markets. Chicago: Probus Publishing Company. 197-221. 